Relations industrielles

Industrial Relations

\title{
Katz, Harry C., ed., The Future of Industrial Relations : Proceedings of the Second Bargaining Group Conference
}

\section{Denis Morin}

Volume 48, numéro 2, 1993

URI : https://id.erudit.org/iderudit/050860ar

DOI : https://doi.org/10.7202/050860ar

Aller au sommaire du numéro

Éditeur(s)

Département des relations industrielles de l'Université Laval

ISSN

0034-379X (imprimé)

1703-8138 (numérique)

Découvrir la revue

Citer ce compte rendu

Morin, D. (1993). Compte rendu de [Katz, Harry C., ed., The Future of Industrial Relations : Proceedings of the Second Bargaining Group Conference]. Relations industrielles / Industrial Relations, 48(2), 358-364.

https://doi.org/10.7202/050860ar

Tous droits réservés @ Département des relations industrielles de l'Université Laval, 1993
Ce document est protégé par la loi sur le droit d'auteur. L’utilisation des services d'Érudit (y compris la reproduction) est assujettie à sa politique d'utilisation que vous pouvez consulter en ligne.

https://apropos.erudit.org/fr/usagers/politique-dutilisation/ 
foisonne. Contrairement à d'autres auteurs, tels Kochan et Katz aux États-Unis et Craig au Canada, qui structurent leurs ouvrages en référence à un modèle ou un cadre d'analyse, le professeur Hébert a plutôt opté pour une démarche chère aux institutionnalistes depuis Commons, privilégiant l'analyse historique et descriptive. D'autres s'étonneront peut-être des prises de positions introduites ici et là par l'auteur afin, souligne-t-il dans son avant-propos, de stimuler la discussion. Les lecteurs assidus du professeur Hébert ne seront cependant pas surpris de retrouver dans cet ouvrage des idées qu'il véhicule depuis plus de vingt ans, telles sa conviction profonde des vertus du système nordaméricain de négociation collective en regard des systèmes plus centralisés des pays européens et scandinaves, et ses critiques acerbes du recours à la grève et de la centralisation bureaucratique des négociations collectives dans le secteur public.

On peut enfin se demander si certains chapitres ne sont pas carrément superflus dans un ouvrage de cette longueur. Les deux premières parties offrent à notre avis une synthèse originale de la portée, des problèmes et des enjeux majeurs de la négociation collective dans les secteurs privé et public au Québec, mais l'utilité de la troisième partie nous semble moins évidente. Il existe de nombreux ouvrages et articles sur les comparaisons internationales et les théories de la négociation collective, et les trois derniers chapitres de l'ouvrage auraient pu tenir lieu de conclusion générale.

Malgré ces quelques réserves, l'ouvrage du professeur Hébert nous apparait comme une contribution magistrale et incontournable, destinée à accompagner tout au long de leur cursus universitaire les étudiantes et étudiants inscrits à des programmes spécialisés en relations industrielles. Les enseignants et enseignantes y trouveront également leur compte, puisque la publication de l'ouvrage de Gérard Hébert vient régler l'éternel problème du choix d'un manuel de référence pour l'enseignement de la négociation collective dans les universités québécoises.

Reynald Boukque

Université de Montréal et Université du Québec à Hull

The Future of Industrial Relations: Proceedings of the Second Bargaining Group Conference, by Harry C. KATZ, ed., Institute of Collective Bargaining, New York State School of Industrial and Labor Relations, Cornell University, 1991, 169 p., ISBN 0-87546-850-0.

Harry Katz introduces this edited volume by observing that it emerged from the Second Bargaining Conference held in the summer of 1990 at the New York State School of Industrial and Labor Relations (Cornell University). This conference serves as a major impetus for our continued effort to understand trends in industrial relations. This book represents a growing trend to publish conference proceedings as books and contains fifteen original papers written by expert contributors.

The book is very impressive, and most of my review will reflect this attitude. I will first describe the book's objectives and its intended audience, then briefly describe and critique each section, and finally, conclude with some general observations. 
The volume has three objectives: to create a forum for the evaluation of existing research in industrial relations; generate new streams of research regarding the field of industrial relations; and to assess the state of current knowledge and project future trends. This volume can be considered a collection of provocative ideas challenging industrial relations researchers.

The authors have done an outstanding job of reviewing the current status of many of the traditional mainstream and newly emerging topics of interest to industrial relations researchers. The papers are clearly designed to inform interested researchers and scholars about detailed conceptual analyses and theoretical positions in various areas of industrial relations scholarly activity. The value of the book resides in its agenda setting function for research. It must be pointed out, however, that the book is heavily weighed toward the world of academia, and so the preponderance of theoretical research makes it hard to believe that practitioners would find it very useful. Readers should have at least an intermediate level of knowledge about industrial relations issues.

It is possible to view this volume as being organized into seven major sections: (1) a critical evaluation of the implications of Europe 1992 for labour-management relations; (2) a discussion of industrial relations in the U.K. in terms of promising research directions and new frontiers; (3) strategic approaches to industrial relations; (4) analysis of human resource management within the industrial relations field; (5) an overview of major research regarding labour law in the 1990s; (6) the influence of state policies on workplace relations; and (7) the current and future status of industrial relations as an academic field. For each of these themes there is a major paper and a commentary paper. Most major papers include a section which describes the implications for research, practice and policy-making as well as future trends and directions. The editor did a good job of ensuring consistency of format, length and tone across the papers.

In reviewing this book, space limitations make it necessary to focus only a few important points. In particular, while I have sought to offer comments on all the papers, only some receive detailed treatment.

James Dworkin and Barbara Lee's paper analyses the impact of EC 1992 on labour relations in American multinational corporations operating in the member countries. After a brief overview of the pre-1992 differences with respect to industrial practice among the twelve member countries, the authors launch into a thoughtful discussion of the impact of the Social Charter on unions and management. Among the conclusions they reach is the proposition that unions will be forced to think and act multinationally. On the other hand, in the short term U.S. firms are far more concerned with the feasibility of mergers with European companies than with changes in the structure of labour relations or worker participation. While most corporations may support an international social dialogue, they are opposed to multinational collective bargaining. In addition, while most employers agree with employee participation on a voluntary basis, they fear that an EC-wide standard for worker participation and consultation rights could lead to a union veto over significant corporate decisions. The authors also suggest that international research in the field of industrial relations will be a major trend in the next decade. The paper ends with a rich listing of specific problems, issues and themes that research might address. In particular the human resource management, labour relations 
and labour economics implications of EC 1992 could generate innumerable research studies.

According to Sarosh Kuruvilla, it is premature to analyze the implications of EC 1992 for labour-management relations at this point of time. The author limits his review to identifying avenues for future research. A question of immediate research interest, in Kuruvilla's view, is to determine the positions of the industrial relations actors across countries on various issues related to industrial relations regulations in the EC. The employment consequences of EC is another area that needs to be addressed in future research.

The purpose of Phillip Beaumont's excellent paper is to evaluate British industrial relations research in the 1970 s and 1980 s in order to suggest a research agenda that promises to advance the field in the 1990s. The author identifies a range of research issues that ought to be addressed by British industrial relations researchers.

The empirical, conceptual, theoretical and historical distinctiveness of human resource management has not been without controversy. There is an important agenda of research necessary to clarify the nature of human resource management. Beaumont adopts an optimistic view by saying that researchers in the human resource management area will increasingly produce a more concentrated or focused stream of research. International studies constitute another promising development as we move into the final decade of the century. The recent challenge of EC 1992 may point the way for such work and should keep researchers busy for years to come. Much closer attention should be paid to individual employment issues in industrial relations. The traditional focus of British scholars has largely been on collective relationships. The development of human resource management, the growth of non-unionism and the decline of union membership, among other changes, has caused the apparent centrality of collective bargaining to be questioned. The significance of these changes provide fertile ground for future studies on the individual aspects of industrial relations. Beaumont encourages industrial relations researchers to more carefully consider the role of the state in industrial relations. A fundamental starting point would be the development of a theory of the state. The second approach that research might take is to focus on the public sector. Research in this major area would help to capture the role of the government actor in the larger system of industrial relations. The issue of management strategy in industrial relations is critically important and deserving of much additional research in the 1990s. This body of research will serve as a catalyst for research examining workforce flexibility. Certainly, more meaningful investigation is needed on the fundamental issue of union recruitment strategies and tactics. Furthermore, the role of women in relation to trade unions is a research issue that might be fruitfully investigated.

David Lewin and William Bigoness' discussions of the potential contribution of industrial relations to human resource management is a refreshing aspect of the book. Such concern appears to be especially salient because collective bargaining, the traditional focus of industrial relations, is increasingly being called into question. Human resource management has risen to the fore during the 1980s. Perhaps the strongest indication of this trend is that in recent years virtually every industrial relations degree program in the United States has changed its name to "Industrial Relations-Human Resource Management'. 
The papers on this topic begin by noting the dearth of empirical research on human resource management as opposed to conceptual treatments of the subject. Lewin asserts that much of the work in the area has been characterized by a strong prescriptive approach rather than by a critical, theory-driven research perspective. One of the key challenges facing industrial relations researchers is to integrate theory and research from human resource management with traditional industrial relations research. Lewin and Bigoless identify some selected issues that warrant further analysis in future research.

More consideration should be given in studies of human resource management to the tension surrounding issues of organizational efficiency versus organizational equity. There have been few empirical studies of the relationship between human resource management policy and organizational outcomes. It is especially timely to study the effect of human resource management policy and practice on business financial performance. Little research has focused on how employee rights can be conceptualized, measured and protected in the absence of unions.

Employee involvement and participation programs have been the subject of a large body of literature in human resource management. Industrial relations could expand the conceptualization of employee involvement and participation programs by incorporating institutional forms of conflict resolution such as grievance procedures in unionized settings and alternate dispute resolution systems in non-union settings. The significance of unionism as a basic form of workplace participation has been a somewhat neglected topic in the human resource management field. Industrial relations suggests that unionism should be considered as a participatory choice available to workers' and employers' organizations.

Industrial relations could provide a bridge between organizational behaviour, with its focus on non-financial participation, and labour economics, with its focus on financial participation of employees in organizations, by integrating both types of participation. Industrial relations researchers need to consider the potential impacts of employee involvement and participation programs on business performance and the protection of employee rights. There has been limited investigation of how the external environment and organizational factors determine the structure of participation programs.

The multidisciplinary focus of the industrial relations field has the potential for providing new theoretical frameworks to human resource management. Industrial relations contributions are increasing in variety and rigour in the field of human resource management. Readers willing to think about the reconciliation of industrial relations and human resource management should find the papers by Lewin and Bigoness fascinating and informative.

Thomas Kochan, Harry Katz and Robert McKersie's paper offers a number of refinements of their well-known strategic choice model, a model which has guided much industrial relations research activity for several years. Kochan, Katz and McKersie argue that the constant interaction between the ideologies and values of top decision-makers, market constraints, technological pressures, business strategies and the public policy context create a dynamic environment in which labour, management and the state make 
strategic choices about how they will handle labour-management relations. These strategic choices explain variations in industrial relations practice.

Kochan, Katz and McKersie then discuss five distinct models of industrial relations practices. They can be summarized as follows: (1) the "traditional New Deal model"; (2) the "traditional non-union personnel management model" which followed the dominant approach of the New Deal model without the presence of unions; (3) a "transformed union model" based on union participation; (4) a "non union human resource model"; and (5) an "associational unionism model".

The authors contribute to the strategic industrial relations research agenda by providing testable hypotheses about the potential link between industrial relations strategies and corporate business strategies. Kochan, Katz and McKersie also postulate that a given industrial relations system works best if industrial relations practices and policies are consistent with the model. They suggest that diffusion of more effective models of industrial relations will be slow unless both government policy-makers and labour leaders endorse the new model.

Kochan, Katz and McKersie argue that the human resource management model is as successful as the union model but where is the empirical evidence? Of direct relevance to the issue, they demonstrated a preference for union model despite the persistence of the human resource management model outlined in The Transformation of American Industrial Relations. Another notable feature of Kochan, Katz and McKersie's paper is a useful discussion of the extent to which the industrial relations field ensures the principle of equity in labour-management. However, the concept of equity in industrial relations needs to be defined operationally.

Richard Peterson's paper contains many thoughtful observations relating to the paper by Kochan, Katz and McKersie that could spark debate among those interested in this area. Peterson does a fine job in noting the limitations of Kochan, Katz and McKersie's discussion while highlighting how future research might overcome these limitations.

There are numerous areas clearly in need of additional theory development and empirical research. For example, little research has been done on the strategic choices of labour and government. Pertinent research could also be conducted on the process by which industrial relations innovations diffuse within firms and across the economy. With regard to the industrial relations and human resource management models identified by Kochan, Katz and McKersie what is badly needed is research that shows whether one model is more effective than another.

The strategic approach to industrial relations is lively, exciting and thriving. We expect to see more theoretical development and empirical work before it attains the status of a validated theory and we hope more policy application of research results.

The section on the future of industrial relations as an academic field consists of a collection of three papers which make for profitable reading. Indeed, this section is one of the unique strengths of the book. The papers examine the forces which have made industrial relations what it is, including its weaknesses and strengths. The authors have provided us with an insightful commentary on the state of affairs of practice, theory and research in industrial relations. They provide a forum of ideas and issues for the purpose 
of provoking a discussion of industrial relations, its past, present and future. While there are some differences in beliefs among the authors, there is a shared belief about the necessity of industrial relations as an academic field.

The discussion on the multidisciplinary tradition and its implications for industrial relations is especially well done. The authors present a convincing argument in favour of the need to supersede our disciplinary fragmentation. Cynthia Gramm suggests the need for greater methodological rigour in industrial relations and goes further by saying that industrial relations is more likely to progress if scholars are open to a variety of research methods.

Peter Sherer's observations on multi-level analysis are perhaps the most interesting part of his paper. Sherer is convinced that the firm is the pivotal unit of analysis in industrial relations. Given this level of analysis, industrial relations scholars need to be sensitive to the sociological perspective. At the same time, the author advocates an effective linking of multiple levels of analysis.

Joel Cutcher-Gershenfeld and Sherer encourage the integration of theory and practice within some areas of industrial relations through their advocacy of an "action theory" perspective. In this reviewer's opinion, the most important statement is that made by Cutcher-Gershenfeld. There is a clear need to appreciate that industrial relations should move toward a broadened focus, integrating theory, practice and policy on all aspects of the employment relationship. Lacunae in the field include: an ambiguity regarding the distinction between industrial relations and human resource management; a gap between research and practice; a dearth of theories regarding the development of labour policy; and barriers to comparative research.

The authors review current issues and/or trends associated with four areas of relevance to research in the field of industrial relations. Sherer notes that we need more studies of business strategy and industrial relations/human resource management, and points out that it is time to become well versed in aspects of internal labour market and manpower analysis. Research on internal labour market may prove to be especially valuable and productive for industrial relations field. Much research time and effort must be devoted to alternate forms of employee representation. Gramm proposes that the topics of women at work and minority workers should constitute an area of inquiry in industrial relations. The field of women at work can benefit from industrial relations' multidisciplinary tradition. In summary, this is a very interesting and thought-provoking section that holds the reader's attention to the end.

At the outset, it is worth noting that the section on forms of employee representation should be essential reading for anyone who is seriously concerned with labour policy. Sockell highlights the central theme of the section: What is the appropriate form of employee representation? It will come as no surprise that the papers presented fall far short of answering this question, but the issue raised is central for labour policy and represents one of the clearest challenges to labour law in the $1990 \mathrm{~s}$.

Donna Sockell argues that recent changes in the structure of the economy and the workplace have made the highly structured employee representation system of industrial unionism, as embodied in the N.L.R.A., obsolete. The forces behind these changes include the growth of the managerial workforce which is excluded from coverage under 
the N.L.R.A., the new emphasis on quality and the importance of teamwork, and the increase of employee participation plans. Various alternate representational forms are discussed. The author presents three models of representation - "associational unionism", "craft unionism", and "enterprise unionism" - and examines the potential legal changes that they might imply as well as their application and relevance for industrial relations practice.

In Richard Block's paper, we find a significantly different position. Block concludes that it is too early to accept Sockell's dramatic conclusion. The point is made that the underlying problems which the new representational forms are designed to address have been accommodated within the current industrial relations system. The author argues that an overhaul of the current system of representation is unnecessary. Even those who disagree strongly with Block will find his arguments of interest. Block provides a useful integrated framework which includes an interesting set of issues when considering representational forms.

In the final analysis, Sockell and Block fail to resolve the issue of representational form. We see the problem and we can suggest solutions, but it is painfully clear that the controversy will not go away.

Stephen Frenkel and George Strauss are the authors of the section entitled "State Policies and Workplace Relations". This excellent section is a valuable contribution to our understanding of the role of the state in shaping industrial relations. The authors provide an insightful and meticulous appraisal of the impact of two contrasting state strategies on workplace relations referred to as Thatcherism (U.K.) and Accordism (Australia). Comparative analysis is clearly at the core of this section.

Frenkel initially examines theories of the state and their connection with workplace relations. He then proceeds to describe the political economy and industrial relations system in Britain and Australia prior to Thatcherism and Accordism. After identifying the core feature of government policies, the author then outlines the changes and trends in workplace relations in the two countries. More empirical research is certainly needed to delineate the impact of state labour policies on workplace relations. Strauss' commentary highlights the growing importance of comparative industrial relations research and provides a model of research methodology in this area.

Overall, I found this carefully edited book to be a significant contribution to the industrial relations literature. It is obvious that the debates on change in industrial relations and the management of human resources will continue for some time. In this volume, this evolution with regard to industrial relations is particularly well addressed. This book raises many very timely issues with the purpose of further stimulating and providing direction for future research. The volume is both instructive and indicative of how far we have to go. Academics and researchers who already have a good grasp on the current state of industrial relations theory will benefit most from reading this book. I highly recommend the book for graduate students as well as my academic colleagues.

Denis MORIN 